\title{
Introdução ao Dossiê
}

Regina Weber*

Pode-se dizer que atualmente existe um certo consenso que etnicidade é um tema forçosamente interdisciplinar. No conjunto das ciências humanas, os historiadores chegaram à temática depois de antropólogos e sociólogos e, por isso mesmo, não há como não lançar mão daquilo já desenvolvido, em termos teóricos e metodológicos, nas ciências vizinhas. Numa esquematização bastante simplificada, podemos situar a primazia dos antropólogos e seus estudos, que remontam ao século XIX, de culturas tribais, a etnologia, seguidos pelos sociólogos, particularmente os da Escola de Chicago, que, desde o início do século XX, analisaram contextos urbanos nos quais grupos sociais de origem diversa - diversidade sempre associada a fenômenos de imigração - passaram a dividir o mesmo espaço. Aquelas que podem ser denominadas modernas teorias da etnicidade têm sido desenvolvidas a partir da segunda metade do século XX, impulsionadas por diferentes fenômenos sociais das sociedades contemporâneas: 1) o surgimento

* Professora do Departamento e do PPG em História da UFRGS.

Anos 90, Porto Alegre, v. 12, n. 21/22, p.45-52, jan./dez. 2005 
Introdução ao Dossiê

do black power, que pôs em cheque as teorias de assimilação desenvolvidas pela Escola de Chicago; 2) o processo de descolonização da África, que deixou aos africanos a tarefa de dividir o poder político em contextos urbanos e aos antropólogos o estudo dos conflitos interétnicos; 3) mais para o fim do século, dois fenômenos, o da globalização, que maximizou as sempre existentes migrações transcontinentais, e o dos novos nacionalismos, muitos deles com base étnica, incentivou a divulgação de teorias já existentes sobre o fenômeno da etnicidade e o surgimento de novas interpretações. É nesses estudos mais recentes que vemos a atuação conjunta de antropólogos, sociólogos e historiadores.

As discussões sobre etnicidade às quais os historiadores engajam-se estão distantes de um gênero de etno-história que estuda grupos tribais e próximas de estudos que se referem a temáticas recorrentes na historiografia, como imigração, nacionalismo e colonização. Mesmo que acontecimentos da Europa contemporânea não tenham expressão na América, como o separatismo étniconacionalista, muitos estudos recentes de fenômenos decorrentes do processo imigratório iluminam acontecimentos de outros tempos dos países americanos, para os quais tal processo está presente em vários momentos de sua história: no povoamento das colônias pelos europeus nos séculos XVI-XVIII, na imigração forçada dos africanos, nos que vieram "fazer a América" no século XIX e nas migrações contemporâneas. É por esta razão que as teorizações mais ou menos recentes da identidade étnica têm permitido uma revitalização dos estudos da problemática da imigração e da nação entre os historiadores. Na historiografia brasileira, sem dúvida, isso é visível.

Mas os historiadores não estão num papel passivo de receptores de teorias e formuladores de casos mais antigos. Na verdade, considerando a importância da trajetória histórica e da representação do passado para a formulação identitária, tanto para os grupos étnicos quanto para as nações, antropólogos já estavam fa-

Anos 90, Porto Alegre, v. 12, n. 21/22, p.45-52, jan./dez. 2005 
zendo às vezes de historiadores ou lançando mão destes em seus estudos. Pode-se dizer, então, que a temática de estudos étnicos constitui-se atualmente de um campo de investigações que tem acumulado formulações teóricas, conhecimentos e análises com a contribuição de diferentes disciplinas das ciências humanas.

Desse campo de investigações, que tem, de um lado, o dinamismo daquilo que está em gestação, de outro, a ausência de um campo conceitual mais definido - ou mais difundido -, o dossiê preparado para este número de Anos 90 visa ser uma expressão.

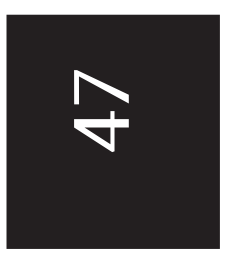
Pretende-se também, justamente, contribuir para a sistematização de interpretações, noções, temáticas, conceitos, que permitam estabelecer um patamar de comunicação que indispensável para a promoção das discussões.

O texto de Karl Monsma, sociólogo por formação e historiador por ofício, é assaz representativo de como a temática da etnicidade abre novos objetos de estudo para os historiadores. Abolida a escravidão, permanecerá a luta simbólica contra a mesma. A insistência dos negros em serem tratados com respeito mostrará o grau de internalização do sentimento de superioridade dos proprietários brancos. As fazendas de café do oeste paulista, no fim do século XIX e nas primeiras décadas do século XX, fornecem uma espécie de "laboratório" para o estudo de relações interétnicas. A presença de imigrantes, principalmente italianos, como administradores de fazendas permite outro ponto de observação das representações étnicas presentes no mundo do trabalho e além dele. Como outras pesquisas que buscam retratar o cotidiano de épocas passadas, a fonte principal de Desrespeito e violência: fazendeiros de café e trabalhadores negros no oeste paulista, $1887-$ 1914 são autos penais.

Temática consagrada pela historiografia, a escravidão também pode ser revisitada pelo enfoque da etnicidade. Utilizando-se da principal proposição de F. Barth, identidade como "categoria de atribuição", Regiane Mattos busca observar, em São Paulo, no

Anos 90, Porto Alegre, v. 12, n. 21/22, p.45-52, jan./dez. 2005 
Introdução ao Dossiê

século XIX, como as classificações externas operadas pela Igreja e pelos proprietários de escravos acabam sendo internalizadas pelos africanos. A constatação da autora de que, no Novo Mundo, diferentes grupos descobrem afinidades que "não imaginavam existir quando estavam no continente africano" lembra processo semelhante dos imigrantes que passaram a ser reconhecidos e a se reconhecerem como "teutos" ou "ítalos" e demonstra o constante processo de reelaboração identitária.

As antropólogas Denise Jardim e Roberta Peters propõem uma aproximação com a história por meio da idéia de "tradição", analisando rituais de casamento de imigrantes palestinos. Num período em que o fenômeno da persistência das identidades étnicas nos quadros dos estados-nação é assunto para o qual historiadores também se voltam, entender como rituais de casamento contribuem para a "fabricação" da coesão social, calcada na noção de uma coletividade dotada de uma origem comum, possibilita dimensionar o grau de enraizamento da identidade étnica nos membros de um grupo que serve de base para tal identificação. A identidade étnica, pode-se dizer, mais do que a identidade nacional, está ancorada na família. Em um dos casamentos acompanhados pela pesquisa etnográfica, a noiva é brasileira e, ao passar pelo ritual do casamento muçulmano com um filho de palestino, ela se torna árabe, mesmo não tendo saído do Estado brasileiro. Para o campo historiográfico que ainda hoje tem, freqüentemente, tratado as formulações identitárias dos diferentes grupos étnicos como previamente estabelecidas - isto é, como "essenciais" -, bastando ao pesquisador recolher números e formas dessa expressão, a sutileza da análise antropológica tem um valor didático.

Os artigos seguintes lidam com uma produção textual que, em maior ou menor grau, é representativa de formas de pensar de épocas e grupos sociais. A própria existência desta produção já indica a possibilidade de indivíduos e grupos sociais refletirem sobre a realidade, expressarem representações ou elaborarem-nas,

Anos 90, Porto Alegre, v. 12, n. 21/22, p.45-52, jan./dez. 2005 
tentando interferir na sociedade. O conjunto de textos comentado por Sílvio Correa difere da produção examinada nos outros artigos, pois tratam-se de obras publicadas no país de origem dos imigrantes, no caso, a Alemanha, que ora alertam sobre os riscos de perda da cultura alemã, ora registram sua manutenção; dito de outra forma, os emigrados permitem ao conterrâneo viajante a reflexão sobre uma identidade que é também uma alteridade. A condição de viajantes de seus autores não os obrigava a definirem uma identidade de emigrados e, talvez por esta razão, seus relatos

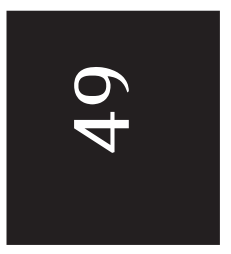
não têm o idealismo que encontramos nos discursos dos líderes de comunidades étnicas. Os relatos de viagem registram a existência de dialetos regionais dos lugares de origem (o que aponta uma falta de unidade de imigrantes que posteriormente representaramse de forma unificada); a vida do colono é retratada mais pela monotonia e privações e do que pelo heroísmo (tal como a saga da imigração desenharia mais tarde). Quando o autor afirma que "não houve uma integração institucionalizada dos imigrantes e seus descendentes durante as primeiras décadas da imigração", estando o construto da identidade étnica baseado em elementos distintivos como a língua e aparência física, é como se se referisse a uma identidade que era objeto de reflexão dos narradores, mas que estava ainda em estado embrionário para os imigrantes.

Os dois próximos textos, além de analisarem representações, indicam o grau de institucionalização dos grupos étnicos. Por "institucionalização" está se referindo ao fato dos grupos terem adquirido um grau de organização social que lhes permite formar sociedades, publicar periódicos ou editar obras comemorativas, instituir datas comemorativas e, num grau mais elaborado, ter seus próprios intelectuais, cuja produção textual não se destina apenas à comunidade, mas também para a sociedade envolvente. Ancorada em um grupo, a memória coletiva torna-se memória social (Halbwachs, 1990). 
Introdução ao Dossiê

Examinando a produção literária da zona colonial italiana do Rio Grande do Sul, Luís Fernando Beneduzi opera com um tipo de interpretação característico dos novos estudos da imigração, qual seja, o de que as representações étnicas são reelaboradas conforme a situação vivenciada pelo grupo "do outro lado do Atlântico". ${ }^{1}$ Lembrando Hobsbawm, podemos dizer que todas as tradições, quando examinadas com atenção são, na verdade, muito recentes. Por exemplo, para o autor, a canção Mérica Mérica, que pertence ao folclore da imigração italiana, "não deixa de ser fruto de um processo de revisão da trajetória da imigração, enfatizando o ponto de chegada, ou seja, a vitória". O cinqüentenário da imigração italiana, em 1925, celebra não apenas a positividade desta imigração, representada, obviamente, pelos seus expoentes mais bem sucedidos, mas a própria lembrança negativa da terra de partida é refeita, afirmando agora a imagem "de uma Itália colonizadora e civilizadora". A vitória, como sabemos, é o engajamento nos parâmetros econômicos do sistema capitalista, visível apenas no século XX, mas, como o efeito de uma representação é tanto maior quanto mais se oculta sua base real, ela fica ancorada num ethos, cujo origem é tão longínqua no tempo que se tornou imemorial, em outras palavras, passou a constituir uma característica "primordial".

Se Haike K. da Silva pode analisar textos que buscam refletir sobre a identidade étnica teuto-brasileira no Rio Grande do Sul já no século XIX, isso não se deve apenas à anterioridade desta imigração no conjunto do que ficou caracterizado como "colonos imigrantes", mas ao fato de que existiu uma parcela significativa de imigrantes urbanos que ou estabeleceram-se na capital da província ou instalaram-se na área colonial em atividades não rurais (professores, párocos, artesãos). Os que "pensaram a identidade", como diz a autora, e o fizeram por escrito para serem lidos por seus contemporâneos estavam, invariavelmente, ligados a uma instituição ou entidade: igreja, escola, editora ou jornal, sendo que

Anos 90, Porto Alegre, v. 12, n. 21/22, p.45-52, jan./dez. 2005 


\section{Regina Weber}

as últimas entidades podiam ser derivadas de uma do primeiro grupo. A formulação intelectual escrita de uma identidade étnica depende da existência tanto de "mentores" quanto de um público receptor de tais elaborações e de canais já criados de divulgação destas publicações. A liderança étnica que Haike Kleber da Silva examina com mais detalhe, J. Aloys Friederichs, condensa várias facetas da trajetória do grupo étnico "alemão". Trata-se de um empresário bem-sucedido, isto é, seu sucesso econômico habilita-o a ser representante do conjunto dos imigrantes. Foi o presidente,

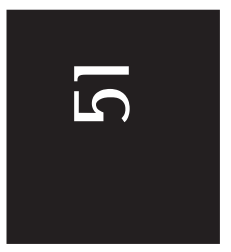
por muitos anos, da mais expressiva entidade associativa recreativa do Sul do País, o Turnerbund (Sociedade de Ginástica), e, como imigrante alemão que se instalava no Brasil, refletiu sobre sua própria condição e sobre a do grupo ao qual estava vinculado. Enquanto os viajantes refletiam sobre uma situação com a qual tinham contato que eles sabiam não ser permanente os intelectuais teuto-brasileiros vivenciavam uma condição da qual suas leituras eram também formas de ação. Portanto, as construções identitárias estão em permanente reelaboração, variando conforme o contexto.

\section{Notas}

\footnotetext{
${ }^{1}$ A expressão é tomada de Ellen Woortmann (2000), que fez uma análise exemplar do processo de reelaboração identitária de imigrantes, estudando o caso dos alemães no Rio Grande do Sul.

${ }^{2} \mathrm{O}$ termo "primordial" é um dos que se tornou indispensável ao linguajar daqueles que estudam etnicidade. Referindo-se ao que é da "essência” dos indivíduos e grupos, primordial opõe-se ao que é "circunstancial" ou balizado apenas pelo interesse. Sobre o assunto, ver Glazer e Moynihan (1975).
} 


\section{Introdução ao Dossiê}

\section{Referências}

BECKER, Howard. Conferência: a Escola de Chicago. Mana, Rio de Janeiro. v. 2, n. 2, p. 177-188, 1996.

GLAZER, Nathan; MOYNIHAN, Daniel P. Introduction. In: (Ed.). Ethnicity, theory and experience. Cambridge: Harvard University Press, 1975. p. 126.

HALBWACHS, Maurice. A memória coletiva. São Paulo: Vértice; Editora Revista dos Tribunais, 1990.

HOBSBAWM, Eric. Introdução: a invenção das tradições. In: HOBSBAWM, Eric, RANGER, Terence (Org.). A Invenção das tradições. Rio de Janeiro: Paz e Terra, 1984. p. 9-23.

POUTIGNAT, P.; STREIFF-FENART, J. Teorias da etnicidade. São Paulo: Editora da UNESP, 1998.

WOORTMANN, Ellen Fensterseifer. Identidades e memória entre teutobrasileiros: os dois lados do atlântico. Horizontes Antropológicos, Porto Alegre, ano 6, n. 14, p. 205-238, nov. 2000. 